\title{
風向正面の場合の通風気流に関する予測精度検証と流管分析
} LES と風洞実験による建物通風気流構造の解明に関する研究（第 1 報）

\section{VERIFICATION AND STREAMTUBE ANALYSIS OF SIMULATED RESULT OF AIRFLOW OF A CROSS-VENTILATED BUILDING FOR NORMAL WIND ANGLE CASE}

Analysis of airflow of cross-ventilated buildings based on LES and wind tunnel experiment (Part 1)

\author{
倉㴊 隆*, 大場正昭**, 岩㴊 拓志***, 島田朋裕**** \\ Takashi KURABUCHI, Masaaki OHBA, Takuji IWABUCHI \\ and Tomohiro SHIMADA
}

\begin{abstract}
Airflow structure of a cross-ventilated model building for normal wind angle case was analyzed using Large Eddy Simulation. Simulated results were in close agreement with experimental observations in view point of flow rate, distribution of velocity vector and turbulence kinetic energy and wind pressure coefficients. Simulated results were analyzed, and it was elucidated that the downfall of the inflow specific to cross-ventilation is strongly affected by pressure gradient due to recirculation on the lower portion on the windward surface of the building. Further analysis was then made to identify shape of streamtube passing through windward opening. Spatial change of static, dynamic and total pressure along the identified streamtube indicated that strong acceleration and deceleration of the airflow does not exert significant change in total pressure at the upstream side of the opening, although energy is exchanged between static and dynamic pressure. This means that flow energy of the streamtube is virtually conserved at the upstream side of the opening, while energy loss occurs after passing through the opening due to the production of turbulence kinetic energy.
\end{abstract}

Keywords : Cross-Ventilation, Large Eddy Simulation, Wind Tunnel Experiment, Streamtube Analysis 通風，ラージ・エディ・シミュレーション，風洞実験，流管解析

\section{1. はじめに}

我が国では蒸暑期における温熱環境の改善手法として通風の有効 利用には関心が高く，建築環境工学の分野でも通風に関する研究は 古くから行われている1)。1960 年代までの成果としては, 勝田によ る平均通風率の提案 ${ }^{2}$, 石原 ${ }^{3}$ による干渉係数や通風時の室内気流 分布のモデル化, 勝田・関根 4)による有風時の開口部圧力損失係数 に関する研究などが挙げられる。その後、しばらく通風に関する研 究にはブランクがみられるが, 1973 年のオイルショック以後, 省工 ネルギーの面から再び通風の有効利用に関心が高まり，清家・小玉

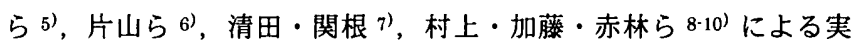
験的研究が成果を上げており, 最近では, 澤地ら 11)による大型風 洞施設による実大建物モデルを用いた検討が注目されている。通風 は建物内外気流が相互に干渉を及ぼす複雑乱流現象であるため実験 的検討は必須といえる。しかし，その本質である静圧・動圧間の工 ネルギーのやりとりや全圧の不可逆的な損失などの要因, メカニズ ムについて解明するためには開口部近傍の静圧・動圧の空間分布の 把握が重要であるものの, その実験的評価は極めて困難であり, 研 究進展の障害となっている。

この問題に対処するため, 近年急速な発展を遂げた CFD 技術を 併用することが考えられ，堤・片山ら ${ }^{12}$ ，倉㴊・鎌田 ${ }^{13)}$ ，飯野・
倉渕・小林・嵐口 $\left.{ }^{14}\right)$ は $\mathrm{k}-\varepsilon$ モデを用いた検討を行い実験と対 比している。また, 富永・村上・加藤・持田 ${ }^{15}$ ) は LES を用いた検 討を行い, 実験と極めて対応のよいことを示している。これらの研 究成果より, $\mathrm{k}-\varepsilon$ モデルはその改良版を含めて, 換気量などの工 学的予測に利用する場合には問題は少ないが, モデル本来の欠点で ある乱流法線応力の近似精度の問題が, 通風のように加減速が重要 な流れ場に適用すると強調され, 乱流構造そのものの再現精度は十 分満足いくものとはならないことが分かってきている。そのため, 実験と併用して通風時の乱流構造を解明するに足る乱流モテルは, 応力方程式系のモデルを別にすれば，現状では少なくとも LES に おける Smagorinsky モデルを選択する必要があると考えられる。

以上の観点から本研究では通風が行われる建物モデルに対し，既 に実施した風洞模型実験 16) に対応した LES 計算を行った。風洞実 験にて測定した通風量, 主要断面における建物内外風速ベクトル分 布, 風圧係数の分布について実験と計算を対比し, LES 計算が十分 な精度で実現象をシミュレートしていることを確認した。しかる後 に, 通風に特有の流入気流の下降要因, 開口部を通過する流管の形 状, 流管中における圧力変化と損失など実験的評価の困難な各項目 について LES 計算結果を分析することによって解明することを試 みた。

\footnotetext{
* 東京理科大学工学部建築学科 助教授・博士 (工学)

** 東京工芸大学工学部建築学科 教授. 工博

*** 元東京理科大学 大学院生・修士 (工学)

**** 東京理科大学 大学院生
}

Assoc. Prof., Tokyo University of Science, Dr. Eng.

Prof., Tokyo Institute of Polytechnics, Dr. Eng.

Graduate Student, Tokyo University of Science, M. Eng.

Graduate Student, Tokyo University of Science 


\section{2. 棓算法概要}

LES による数値シミュレーションを実施する場合, 流入境界条件 となる風洞アプローチフローの再現が問題となる。この点に関し， 現状ではチャンネル乱流の数值シミュレーションを別途実施し，ス トックデータを風洞実験に適合するように加工して用いる手法が一 般に用いられている 17)。本報でも既往研究を踏㢣し，事前に実施し たドライバー計算によるストックデータから流入条件を作成した。 以下に LES の計算における設定条件の概要を示す。

\subsection{SGS モデルと壁面䚈界桑件}

本報では最も適用実績が多く基整的な Smagorinsky モデルを用 いることにしたが, 計算定数に関しドライバー計算では, チャンネ ル乱流で一般に使用される Smagorinsky 定数 $\mathrm{Cs}=0.1$ を,本計算で は $\mathrm{Cs}=0.13$ とした。また, 本計算に用いる平滑面用の壁面境界条件 としては，以下に示すカルマン三層モテルを数值近似し，陰関数を 陽的に処理可能な関数形に変更した近似式(1)〜 (3)を用いた ${ }^{18)}$ 。
$\left(u . / u_{P}\right)^{2}=1 / \mathbb{R e}_{h}$
$\operatorname{Re}_{h}<25$

$\left(u_{*} / u_{P}\right)^{2}=1.829 /\left(\ln \operatorname{Re}_{h}\right)^{3.270} \quad 25 \leq \operatorname{Re}_{h}<420$

$\left(u_{0} / u_{P}\right)^{2}=0.1464 /\left(\ln \operatorname{Re}_{h}\right)^{1.866} \quad 420 \leq \operatorname{Re}_{h}$

ここに、 $u^{n}$ : 摩摖速度， $u_{\mathrm{p}}$ : 壁に隊接するセルの瞬時スカラー風速, $\operatorname{Re}_{h}: u_{p}$ とその定義点の壁からの距離 $h$ に基づく Re 数,である。

粗面を想定するドライバー計算では, 面の粗度 $k_{S}$ とカルマン係数 $\kappa$ をえ，以下の式によって摩擦応力を求めた。

$u_{P} / u_{0}=1 / \kappa \ln \left(h / k_{s}\right)$

なお，ドライバー計算，本計算共壁近傍に位置するグリッドフィ ルタに次式に示す van Driest 型の壁減衰関数 $f_{\mu}{ }^{19}$ を乗じている。

$f_{\mu}=1-\exp \left(-h^{+} / 25\right)$

ここに, $h^{+}$: 壁座摽（瞬時の摩擦速度, 壁からの距離 $h$ による)で ある。

\section{2 定国量型周期境界案件}

LES におけるチャンネル乱流の計算では, 壁面以外の境界には周 期境界条件の適用が一般的である。しかし，主流方向に一定の圧力 差を仮定して周期境界条件を適用すると，計算される風量が意図し た値になるとは限らないこと，風量が時間的に変動することなど， 実用上の問題がある。そこで, 今回は主流方向の風量を常に想定值 に固定することが可能な定風量型境界条件を開発し，適用した。簡 単のため二次元問題とし, 主流方向空間分割 $\delta \boldsymbol{X}$, 主流と直交方向 空間分割 $\delta \mathrm{y}$, 主流方向分割数 $L$, 陽解法時間分割 $\delta t$, スタカード 配置とすると, 境界面における $\mathrm{n}+1$ 時点の風速は形式的には次式の ように表すことができる。

$$
u_{B, j}^{n+1}=u_{B, j}^{\circ}+\delta t / \delta x\left(p_{L, j}^{\prime}+\Delta p^{\prime}-p_{1, j}^{\prime}\right)
$$

ここに, $u^{\alpha}{ }_{B, j}$ : 境界面風速（ $\alpha=*: \mathrm{n}$ 時点の圧力, 運動量フラッ クスを用いて求めた㫌定値， $\alpha=\mathrm{n}+1$ : 更新值)， $p_{i, j}^{\prime}$ : 圧力の修正 量, $\Delta p^{\prime}$ : 周期境界における圧力差の修正量である。

式（6）に基づいて圧力修正量に関するポワソン式を作成し，マト
リクス表示すると周期境界条件を処理するために必要な 2 バンドに 加えて、未知数 $\Delta p^{\prime}$ に関わる係数を収容するため列べクトルが 1 つ增える。未知数の増加に対応して風量を設定するための次式が追 加される。

$$
Q=\sum_{d j}\left[{ }^{*} u_{B, j}+\delta t / \delta x\left(p_{L, j}^{\prime}+\Delta p^{\prime}-p_{1, j}^{\prime}\right)\right] \delta y
$$

ここに、Q: 設定風量である。

この方法を適用することにより設定風量は常に一定となるが，周 期境界における圧力差の時間変動は許容することになる。なおこ の方法を用いてもマトリクスの対称性は保持される。また，主流と 直角方向に周期境界条件を適用する場合は圧力差を 0 とおいて，風 量をなりゆきとする従来:の周期境界条件を用いた。

2.3 スキームとソルバ-ー

空間微分には中心差分，時間微分には Adams-Bashforth スキー ムを用いた。ソルバーとしては CG 法を適用したが，前処理として 対角項のみに fill-in の影䉕を考慮した修正不完全コレスキー分解を 行った。なお，周期境界の圧力差修正量に関わる倸数は，pの式に fill-in を生じることはなく，この部分のコレスキー分解は近似なし に行うことが可能である。

\section{4 ドライバー棓算}

床面を粗度のある壁面とし，天井面を鏡面，主流方向(風单規定)， スパン方向（圧力一致）を周期境界条件でつないだ。計算における 主流方向中央断面にてスパン方向 $\mathrm{y}$ ，铅直方向 $\mathrm{z}$ の瞬時風速デー夕 をストックし，ストッグデータが本計算のメッシュシステムに適応 するように直線補間を行い， $\mathrm{z}$ 方向において平均速度分布が風洞実 験と概ね一致するように補正を行った。補正前の流入風速 $U$ のプロ フィル, 乱流エネルギー $k$, 補正後の $U$ のプロフィルを図 1 に示す が， $k$ 值はやや実験より低くなった。なお，以下では建物高さ，建 物高さにおけるアプローチフロー風速で計算結果を無次元表示する。
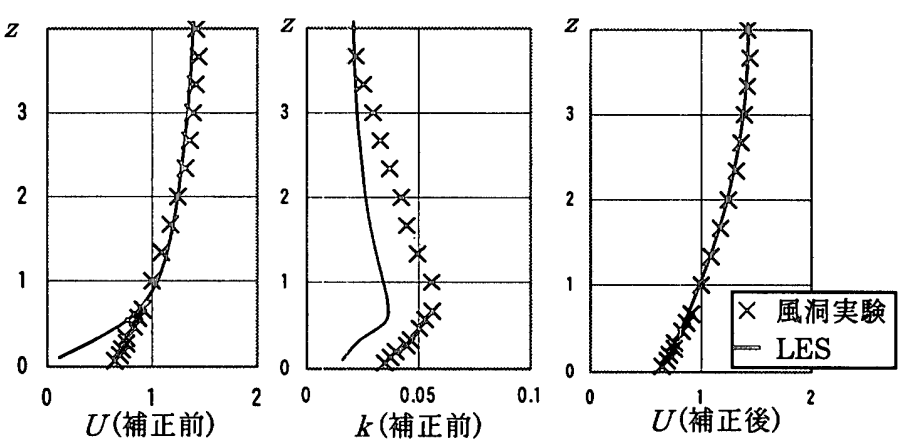

图 1 流入平均風速と乱流工ネルギー

\section{5 本計筑}

計算対象空間は $13.0 \times 8.00 \times 6.66$ の空間を $100 \times 94 \times 61$ のメッ シュ分割を施したものにした。また対象建物として $2.0 \times 2.0 \times 1.0$ の単純形状建物を想定し，開口なしのもの，上流面と下流面に開口 を有するもの（開口部サイズ : $0.4 \times 0.2$, 開口部厚さ方向 2 メッシ ユ）の計 2 タイプの計算を行った。図 2 に一例として開口ありのパ ターンのメッシュレイアウトを示す。流入条件は先のドライバー計 算により作成したものとし，流出条件は瞬時断面平均風速を用いた オイラー型境界条件とした。風洞装置を想定し天井，床，側面を壁 
面とし，壁面は平滑面を想定した。本計算は予備計算により解が概 ね定常到達後に, 20 万ステップの本計算を実施し, 計算結果を統計 処理して実験と比較した。なお，LESにおける乱流エネルギー $k$ の 計算結果についてはグリッドスケール成分に加えてサブグリッドス ケール成分 $k_{S G S}$ を以下の式で評価して加えている。

$$
k_{S G S}=v_{S G S}^{2} /\left(C_{k} \Delta\right)^{2}, C_{k}=0.094
$$

ここに, $\nu_{S G S}$ : SGS の渦動粘性係数, $\Delta$ : グリッドフィルター幅,

$C_{k}: v_{S G S}=C_{k} \cdot k_{S G S}^{1 / 2} \cdot \Delta$ とおいた場合のモデル定数である。

\section{3. 計算結果と実験結果の比較}

\section{1 通風量の比較}

表 1 に通風量の比較を示す。LES は良好に実験を再現している。 なお, 先行して実施した $\mathrm{k}-\varepsilon$ モデルによる計算 20)でも, 通風量に 関しては同程度の精度の結果が得られている。

\section{表 1 通風量の比較（無次元値）}

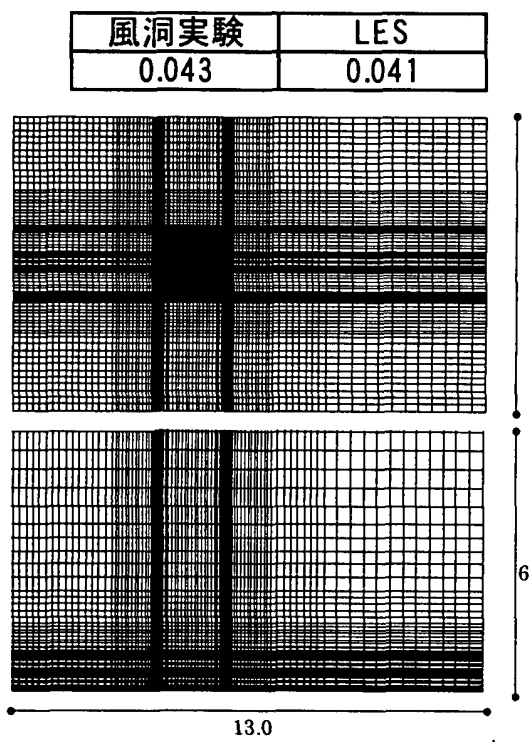

図 2 メッシュレイアウト
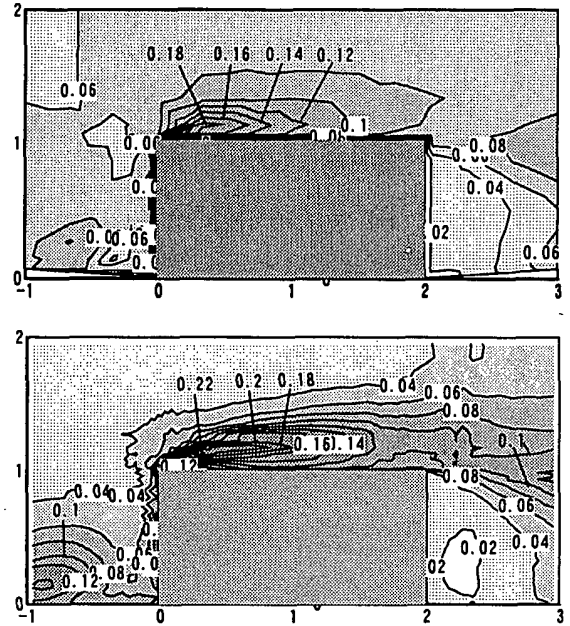

図 5 開口なしの風洞実臨 (上)と $\operatorname{LES}($ 下)の乱流エネルギー

\section{2 風速ベクトルの比較}

図 3，4に開口なし，ありの場合における対称面の時間平均風速 ベクトルの比較を示す。これによると周辺気流の特徵である建物上 流側の渦, 屋根面での剥﨎, 後流の様相などが的確に再現されてい る。また，開口ありの場合における室内流入後の気流の著しい下降 は岩本ら 21) と同様に再現されており，良好な対応を示している。 この点に関しては， $\mathrm{k}-\varepsilon$ モデルより予測精度は格段に向上したと 判断できる。

\section{3 乱流エネルギーの比較}

図 5，6 に開口なし，ありの場合における乱流エネルギーの比較 を示す。乱流エネルギーに関しては，建物前面下部や屋根面前緑が ピークとなり，そのオーダーも概ね一致している。建物内部に注目 すると，上流側開口部の風下側で乱流エネルギーが比較的大きい值 をとり，斜め下方に流入する主流に治って拡散している。後流域に ついては，屋根面下流側での乱流エネルギーのレベルがやや高い点 は相違するものの全般的に分布性状はよく再現しているとみられる。
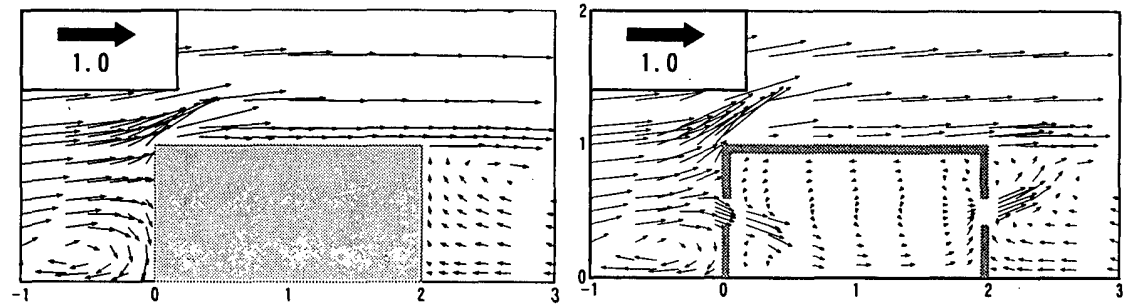

8.0

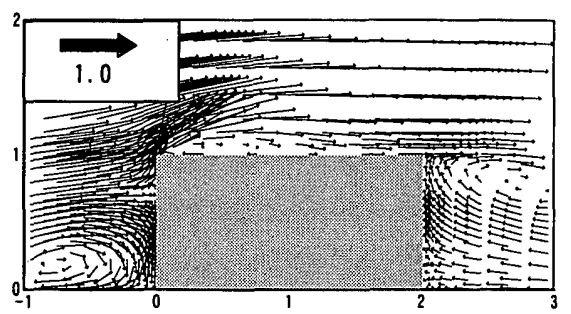

图 3 開口なしの風洞実験 $($ 上) と $\operatorname{LES}($ 下) 風速ベクトル図

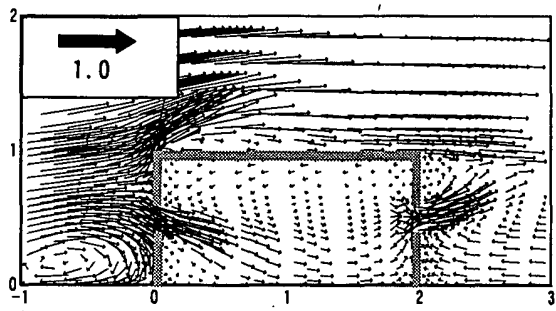

図 4 開口ありの風洞実跧(上) と LES(下)風速ベクトル図

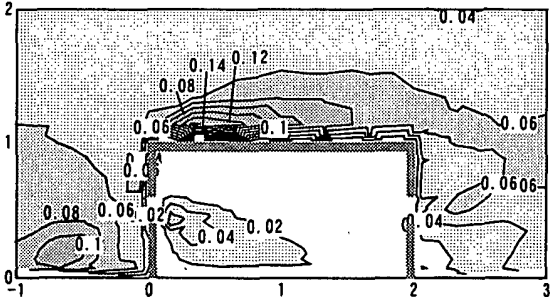

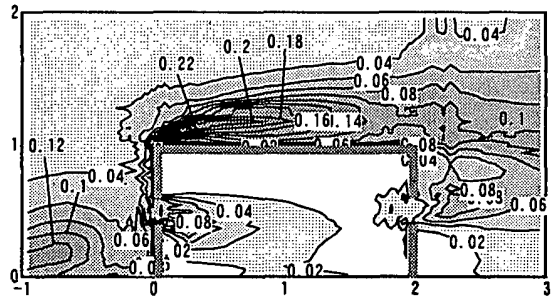

图 6 開口ありの風洞実験(上)と LES(下)の乱流エネルギー
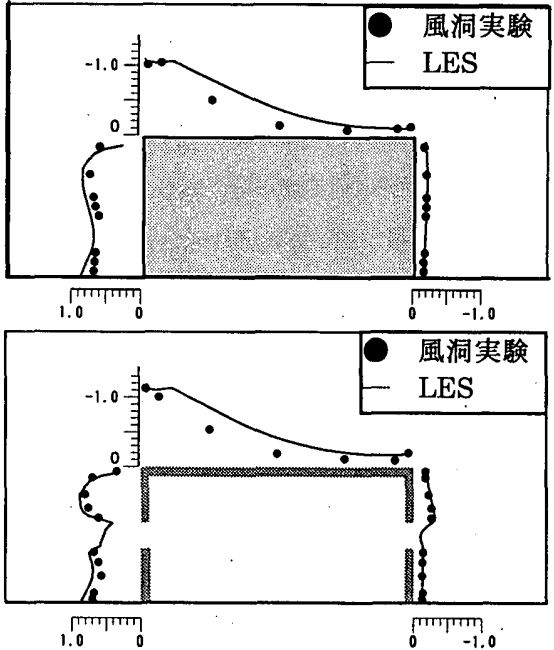

図 7 中心軸における鉛直断面風圧係数 (上：開口なし 下：開口あり） 


\section{4 風压係数の比较}

図 7 に開口なしの場合，ありの場合の建物外周壁風圧係数に関す る比較を示す。建物前面における風圧係数は, 実験に比べて多少大 きいものの, $\mathrm{k}-\varepsilon$ モデルで特徴的な極端な過大評価は見られず, 特に開口ありの場合，なしの場合に比べて開口部上部で風圧係数が わずかに増加する点を含めて，害験を比較的良好に再現している。 また，風下面では開口ありの場合，なしの場合に比べて開口部上部 の負圧がかなり增加する傾向が見られるが，この点についてもよく 対応しており，屋根面についても概る一致していると判断できる。

\section{4. 計算結果の分析}

前節の結果より，LES による計算結果は既往実験による風速べ クトル，風圧力，乱流エネルギーについて， $\mathrm{k}-\varepsilon$ モテルよりも格 段によく対応することが判明した。従って，実験的評価が困難な量 に関しても，今回の計算結果はかなりの精度で実状を反映している と期待することができる。そこで，以下では通風で特徴的な三項目 についての分析を試みた。

\section{1 流入気流下降の要因}

今回検討している通風気流の特徵として，流入気流の著しい下降 が挙げられる。この原因を解明するために，開口部中心を通る中心 軸に治って，力の収支を求めることを試みた。まず，時間平均した 鈶直方向速度成分の運動方程式は，次のように表される。

$\frac{\partial W}{\partial t}=-\frac{1}{\rho} \frac{\partial P}{\partial z}-\frac{\partial U_{j} W}{\partial x_{j}}-\frac{\partial}{\partial x_{j}}\left[\overline{u_{j} w}-v\left(\frac{\partial W}{\partial x_{j}}+\frac{\partial U_{j}}{\partial z}\right)\right]$

粘性と想定空間の対称性からスパン方向微分を無視すれば，以下の ように簡略化して表すことができる。

$\frac{\partial W}{\partial t}-\frac{1}{\rho} \frac{\partial P}{\partial z}-\frac{\partial U W}{\partial x}-\frac{\partial \overline{u w}}{\partial x}-\frac{\partial W^{2}}{\partial z}-\frac{\partial \overline{w^{2}}}{\partial z}$

ここに， $U_{\mathrm{j}}: x_{\mathrm{j}}$ 方向の平均風速，W: 上向きを正とする鈶直方向 平均風速， $x$ ；:テカルト座標， $U$ : 主流方向平均風速， $u$ : 主流方 向瞬時風速, $x$ : 主流方向座標, $z$ : 鈶直方向座標, $u_{\mathrm{j}}: x_{\mathrm{j}}$ 方向瞬 時風速, $W$ : 銛直方向瞬時風速, $P$ : 平均圧力, $\nu$ : 動粘性係数, $\rho:$ 密度である。

図 8 に検討した開口部中心軸とその周辺の平均気流場，図 9 に銷 直方向平均速度（上向きを正）及び, 式(10)における各項の大きさ を具体的に評価した值を示す。なお，式(10)の右辺の合計は概ね 0 となることを確認しており, 計算解の振動を除去するため軸方向に 計算結果を平滑化している。まずアプローチ気流は, 開口部位置·1.2 地点付近で循環流端部に達し，循環の外周に治って建物に接近する。 この領域は主流方向速度がほほ一定で鉿直速度が正から負に変化す るため, 式(10)の右辺第二項は正となる。開口部に十分接近すると Wは負値を維持した状態で主流方向に加速が生じ，同じく正佔をと るため, 図 9 に示すようにこれらの領域で第二項は大きな正の値を とる。また循環域では進行方向への の正の寄与も無視できない。流れを下降させる要因は，これらの作 用を相殺する式(10)中の負成分と考えられるが，図 9 より-1.2 付近 から開口部近くまで, 式(9)右辺第一項の圧力項が対抗していること が分かる。その後開口部に十分接近すると圧力項も正へと転じ,

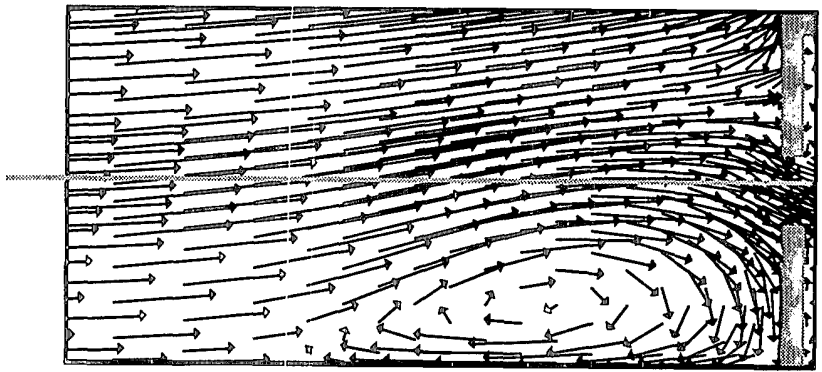

图 8 開口部中心軸とその周辺の平均気流畦
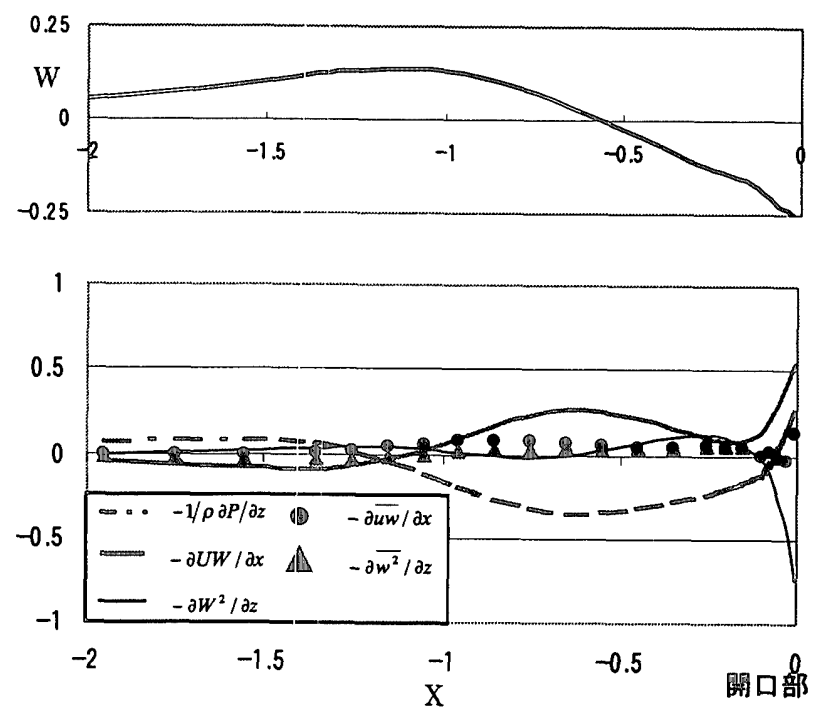

园 9 铅直方向成分の風速と成分項每の比較

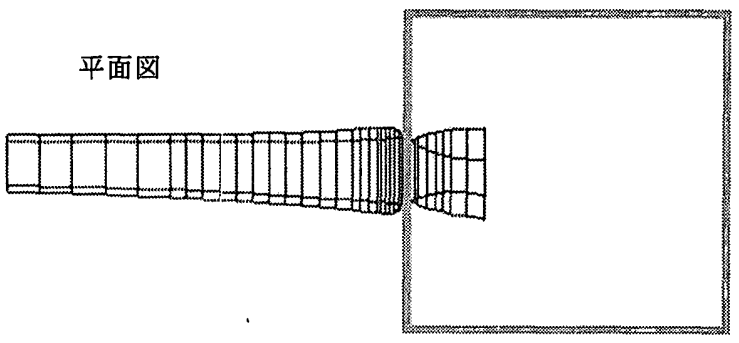

立面図

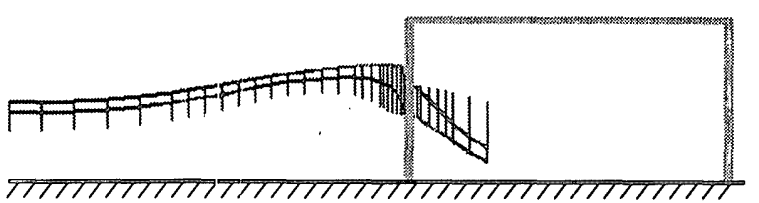

透視図

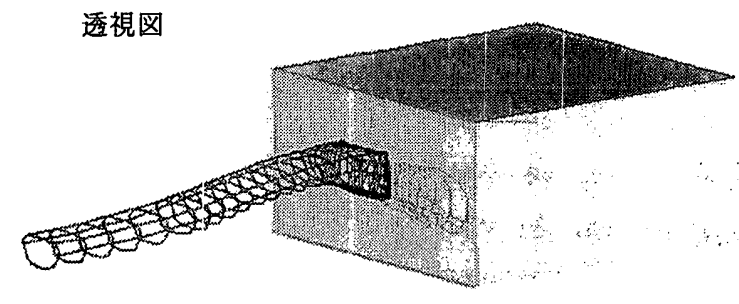

图 10 流管の樴椙 
唯一負値となるのは第四項の $W$ 成分による運動量輸送となるが,こ れには開口部より上部に位置するよどみ点で分岐した下降流による 運動量輸送の影響が大きいと考えられる。このように流入気流下降 の要因の一部には, 建物前面下部の循環流による圧力勾配があり, 流入前の最終段階では下向き運動量輸送が重要となることが分かっ た。

$\mathrm{k}-\varepsilon$ モデルでは, 風向正面の場合における通風気流の下降が十 分再現されないことが問題となっていたが，上記分析より建物前面 下部の循環流が正しく再現されないことが一因であると推定された。 4.2 開口部を通過する流管の形状变化

全圧損失のメカニズムを解明することを目的として, 風上側開口部 を通過する流管形状の同定を試みた。計算は開口部を $100 \times 100$ に 分割してマーカーを飛ばし，各計算メッシュを通過するたびにその 地点での風量, 流断面積等を計算する方法を用いた。風量は連続条 件式を考慮して, 各セル表面での法線方向風速成分の大きさは一定 として計算し，その他の量については直線補間を用いた。なお，各 流断面における風量差は 8\%以内に収まった。開口部上流側では計 算領域の流入境界まで遡ることが可能であったが，室内側では流管 がねじれて十分下流までの追跡は不可能となった。図 10 に計算し た流管の平面，立面，透視図を示す。流管は当初，開口部よりやや 小さい流断面積を維持して開口部方向に直進するが，建物前面下部 での循環流に押し上げられて上昇しつつ，スパン方向に引き伸ばさ れ，その後の下降に伴う減速によって急速に流断面積を増し，開口 部に十分接近すると再び加速して縮小し, 開口部に流入する。なお, 流管は開口部に到達以前に風上壁面に接することはない。室内に流 入後は急速に流断面積を增やして減速しつつ下降する。図 11 に流 管の断面積と風向角度の関係を示す。これによると流管の面積が開 口部直前で急激に増加することや，開口部直前において風向が下向 き約 40 度に達していることが分かる。このように, 開口部を通過 する流れは, 減速, 加速, 減速が短い区間で生じる複雑な流れによ り形成されていることが分かった。

\section{3 平均流のエネルギー変化}

粘性の影響を無視した平均流のエネルギー輸送方程式は以下のよ うになる。

$\frac{\partial K}{\partial t}+\frac{\partial}{\partial x_{j}}\left[U_{j}(K+P)\right]=-\frac{\partial}{\partial x_{j}}\left(U_{j} \overline{u_{i} u_{j}}\right)+\overline{u_{i} u_{j}} \frac{\partial U_{i}}{\partial x_{j}}$

ここに, $K:$ 平均流の運動エネルギーである。

これを流管に適用すると，流管の断面間での全圧差は検討区間の 流管表面における仕事と流管内部の乱れの生産に対応することが分 かる。まず，図 12 に開口部中心軸に治った静圧，動圧，全圧の変 化を示す。全圧が開口部上流側で大きく変化しているのは，気流の 軌道を無視しているためと判断された。そこで，流管に浻って流管 内部の流量による重み付け平均で表した結果を図 13 に示す。アプ ローチフローは開口部に到達するまで，加減速による静圧，動圧間 でのエネルギー変化が生じるが, 全圧変化は非常に小さい。流管が 開口部に達すると，まず大きな静圧低下が生じ，開口部通過後に動 圧と静压の低下が同時に生じている。この開口通過直後に生じる全 圧損失について検討するため, 図 14 に乱流エネルギーの生産項の空 間分布を示す (SGS 成分の寄与は無視)。開口部下流側，特に開口 角部を中心として乱流エネルギー生産が大きくなっており，全圧の
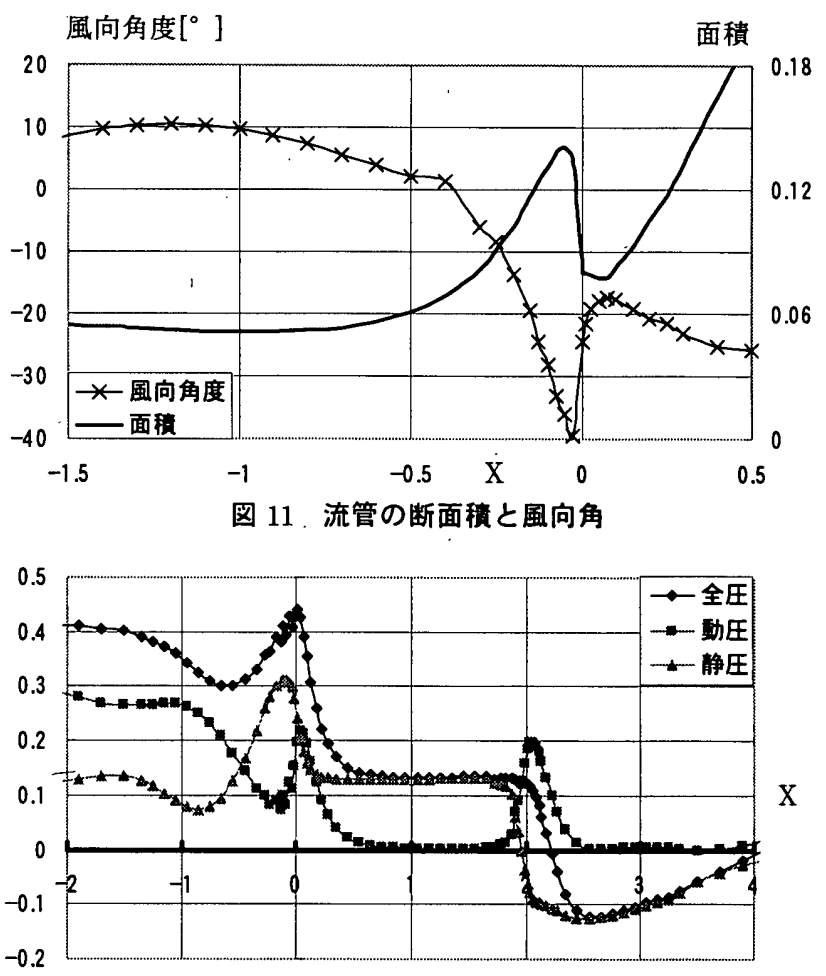

図 12 中心軸における圧力分布

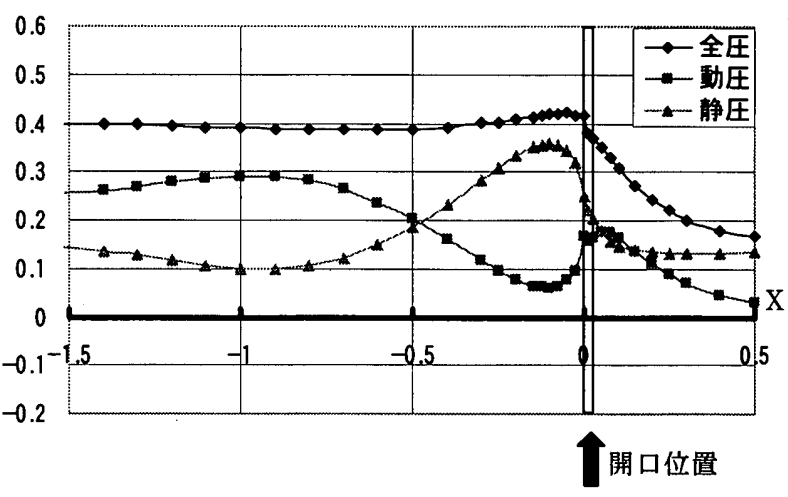

图 13 流管における圧力分布

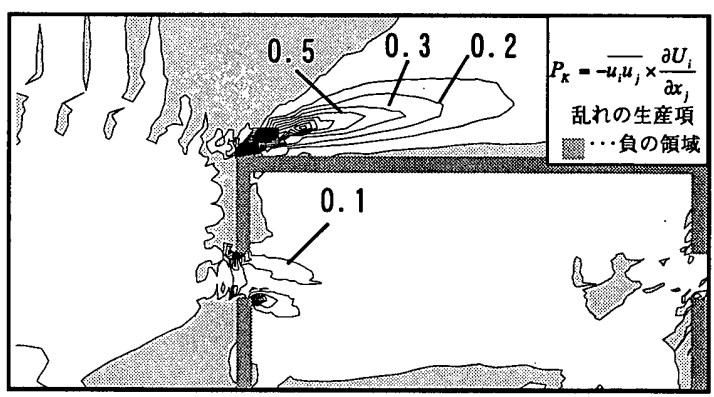

図 14 乱流エネルギー生産項 $\mathrm{P}_{\mathrm{k}}$

低下傾向と対応していると判断される。全圧の大きな低下はこのよ うに通風気流が室内に流入した直後に生じるため, 室内を進行して 下流側の壁面に達する時点では流入時点での全圧は室圧基準で大部 分失われ, 再び大きな乱流エネルギーを生産する余力は残されてい ない。なお，全圧損失は動圧損失の 1.6 倍となった。 


\section{5. まとめ}

風向正面の場合における通風時建物内外気流構造解明のために, 模型の大きさが同一で開口なしとありの場合の計算を行い，実験と の比較検討に基づき考察した結果，次の知見を得た。

（1）LESの計算結果は通風量, 風速ベクトル, 乱流エネルギー，風 圧係数等の統計量に関して風洞実験結果とよくに対応し， $\mathrm{k}$ $\varepsilon$ モデルに対し，大きな改善がみられた。

この結果を踏まえて開口ありの場合の計算結果を分析し, 通風時 に特徵的な要因について検討を行った結果, 次のような知見を得た。

（2）風向正面の場合に特徵的な流入気流の下降は, 開口部に接近す る前半では建物前面下部に形成される循環流による圧力勾配, 後半では平均流の運動量輸送の影響によることがわかった。 $\mathrm{k}$ - $\varepsilon$ モテルを用いた場合に, 気流の下降が十分に再現されない のは, 循環流の形成が不十分であることが原因と考えられ，こ の点に関するモテルの改善が必要と判断された。

（3）開口部を通過する気流のエネルギー変化を分析するために流 管形状を同定した。その結果, 開口部付近の短い区間での加減 速の影響により，この区間の流管形状に大きな変化が生じてい ることが明らかとなった。

（4）しかし, 開口部到達以前の流管変形に伴う動圧, 静圧間のエネ ルギーのやりとりは全圧に顕著な変化を与えない。従って, 風 向正面の場合の全圧損失は, 気流が開口に到達以後に生じるも のであり,これは, 乱流エネルギー生産項の空間分布とも対応 する結果となった。

\section{本論文に関する既発表文献}

1）岩刹拓志，倉㴊 隆，崖口晃宏，大場正昭：LES における非対称チャ ンネル乱流に基くアプローチフローの再現に関する研究，日本建築学会 関東支部研究報告集，pp241-244，1998 年

2）小橋史彦, 倉㴊隆, 大場正昭, 風口晃宏, 岩浂拓志: 通風時の建物内 外気流楧造解明のための数值シミュレーションに関する研究（2）LES （Sモデル）による解析と計算結果の詳細解析，日本建築学会関東支部 研究報告集, pp.221-224, 1999 年

3）岩洋拓志，倉㴊 隆，嵐口晃宏，大場正昭：通風時建物内外気流の構造 解明を目的とした LES シミュレーション, 空気調和・衛生工学会学術 論文集，pp.1185-1188，1999 年

4) 岩㴊拓志, 會㴊隆, 大場正昭, 嵐口晃弘, 小橋史彦: 通風時建物内外 気流構造解明のための数値シミュレーションに関する研究(4) LES(S モデル)による計算結果と風洞模型実験の比較, 日本建築学会大会学術 講演梗概集，琪境工学II，pp.703·704，2000 年

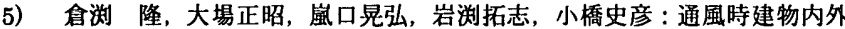
気流構造解明のための数值シミュレーションに関する研究(4) 計算結 果に基づく通風時の乱流構造の解明，日本建算会大会学術講演梗概集， 琹境工学 II，pp.705-706，2000 年

6) Kurabuchi T., Ohba M., Arashiguchi A., and Iwabuchi T.Numerical Study of Airflow Structure of a Cross-Ventilated Model Building. Air Distribution in Rooms:Ventilation for Health and Sustainable Buildings. ROOMVENT 2000 Vol.1, 313-318, ELSEVIER, 2000
参考文献

1） 日本建築学会環境工学委員会空気罗境運営委員会 : 通風量算出のモデリ ング, 空気買境運営委員会第 1 回空気シンポジウム, 1990 年

2）睠田高司：自然換気に関する実験的研究，東京大学生産技術研究所報告， 第 1 巻, 第 2 号, 1950 年

3）石原正雄 : 建築換気設計, 朝倉畫店, 1969 年

4）勝田千利，関根 毅：建物壁面開口部による換気に関する実験的研究 その 1 ，特に開口部の圧力損失倸数と風圧係数について，日本建築学会 論文報告集，第 68 号，pp.1·9，1961 年

5）清家 清，小玉祐一郎，高田典夫 : 室内空間形態の通栭性状に及ぼす影 響について，模型実験による風速分布と通風量の測定(1), 日本建築学会 大会学術講演梗概集, pp.243-244, 1977 年

6）片山忠久，石井昭夫，西田 勝，堤純一郎他：通風に関する模型実験法 の研究(その 1,2$)$, 日本建築学会大会学術請演梗概集, pp.375·378, 1985 年

7）清田誠良, 関根 毅 : 㯕型壁面の夏期後部圧力損失に関する実験的研究 日本建築学会環境工学棆文集，第 6 号, pp.77·83， 1984 年 村上周三，小林信行，洳藤信介，赤林伸一 : 住宅の自然通風に関する 実験的研究 (その 1) 実測と風洞模型実験による天空の通風効果を中心 として，日本建築学会論文報告集，No.372，pp.10-20，1987 年

8）赤林伸一，村上周三，加藤信介他：住宅の換気・通風に関する研究 そ の 6, 7, 日本建築学全大会学術講演梗概集, pp.629.632, 1989 年

9）赤林伸一，村上周三，加藤信介他 : 住宅の換気・通風に関する研究 そ の $8 \cdot 10$, 日本建築学会大会学術講演梗概集, pp.547·552, 1990 年

10）摆地孝男，瀬戸裕直，清田誠良，成田健一，阿部县美：住宅の通風設計 および性能評価に関する研究 その $1 \sim 3$, 日本建築学会大会学術講演梗 概集，濖境工学 II , pp.525·530，1999 年

11）片山忠久，堤純一郎，林 徹夫，吉永久雄，渡辺哲也：通風時における 室内気流分布の数值シミュレーション(その 1，2), 日本建策学会大会学 術講演梗概集，pp.483·486，1989 年

12）倉洋 隆，鎌田元康：Multi-Mesh 法を用いた通風時建物内外気流の同 時解析, 日本建筑学会計画系論文報告集, No.426, pp.1·11, 1991 年

13）飯野由香利，倉浂 隆，小林信行，嵐口晃宏 : 風洞実鈳および CFD を 併用した通風時の建物内外の気流性状に関する研究，日本建築学会計画 系論文集，No.520，pp.47·54，1999 年

14）富永祯秀, 村上周三, 加藤信介, 持田 奵: 通風時の建物内外気流の Large Eddy Simulation 速度・圧力場に関する風洞実験との比較とエネル ギー損失過程の解析，日本建築学会大会学術講演梗概集，pp.497·498， 1991 年

15）大場正昭，倉㴊 隆，入江謙治 : 通風開口部の流入気流と圧力損失に関 する実験的研究，日本建築学会計画系墖文集，2002 年（投稿中）

16）大岡龍三，持田奵，村上周三，林吉彦：風洞実験及び LES, DSM との比較による ASM の精度・問題点の検討 ASM による立方体周辺の 非等方乱流場の数值解析, 日本建策学会計画系論文集, No.495, pp.61-68, 1997 年

17）倉㴊 隆，鎌田元康：非等温室内空気分布数值予湘法の壁面境界条件に 関する研究 一垂直加熱平板自然対流に関する検討一，空気調和・脌生 工学会学術講演会講演論文集, pp.565·568, 1988 年

18）持田 奵，村上周三，富永禎秀，小林 光: Smagorinsky SGS モデル における標準型とDynamic 型の比較 Dynamic LESによる 2 次元角柱 まわりの乱流瀜放出流れ解析 (第 1 報)，日本建築学会計画系論文集 No.479, pp.41·48, 1996 年

19）鈴木求紀，倉㴊 隆，大場正昭，嵐口晃弘，岩㴊拓志：通風時建物内外 気流構造解明のための)数值シミュレーションに関する研究(3) 標準 $\mathrm{k}$ - $\varepsilon$ モテル, 改良モデルの比較検討, 日本建箱会大会学術講演梗概集, 環境工学 II, pp.701·702，2000 年

20）中越淳郎, 岩本静男, 今野 雅: 通風室内外の気流性状の数値解析, LES と $\mathrm{k}-\varepsilon$ モデルの比較, 空気調和・衛生工学会講演論文集, pp.681·684 1998 年 